
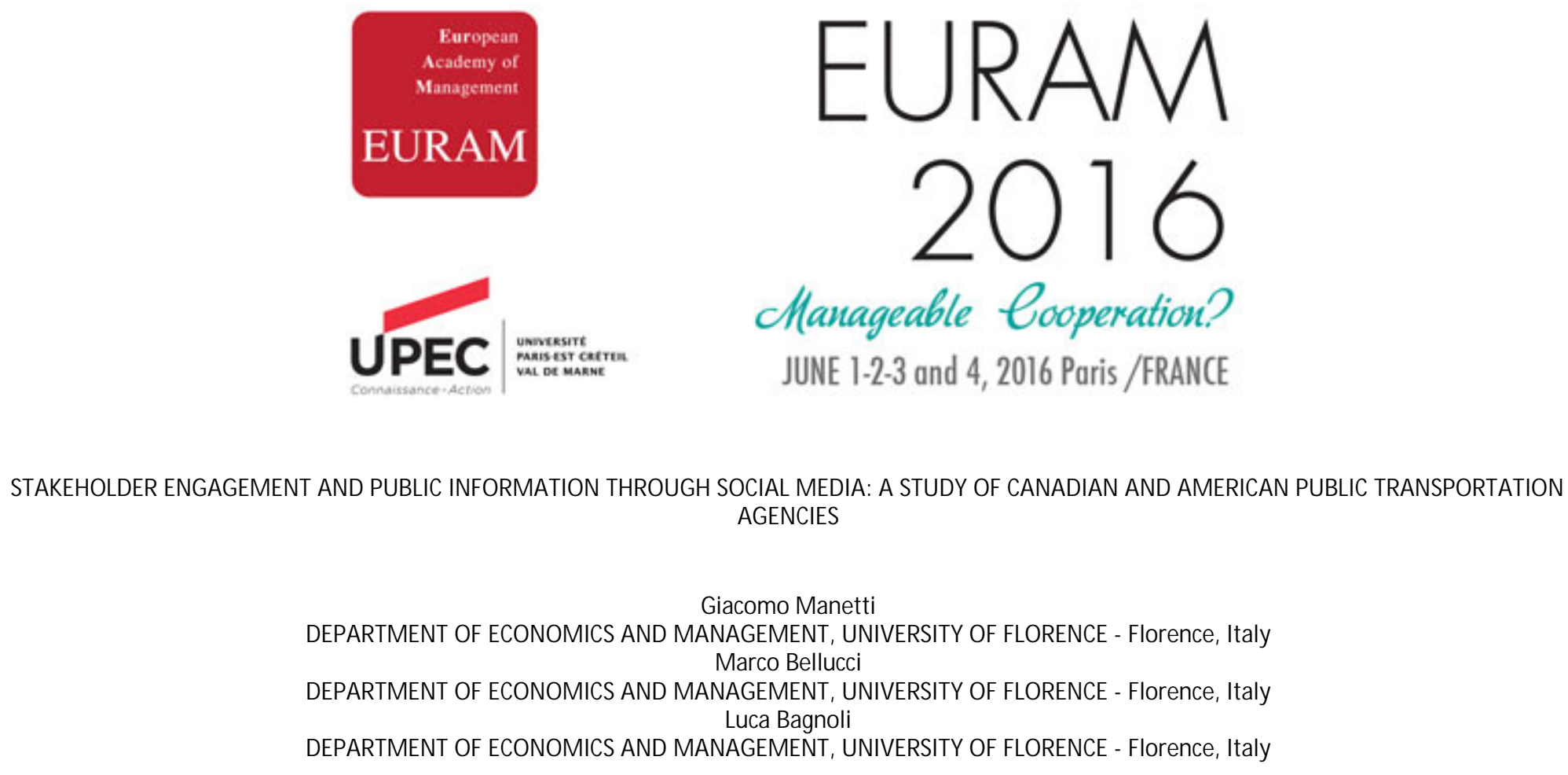

Category: 11 PUBLIC AND NON-PROFIT MANAGEMENT \11_03 ACCOUNTABILTY, SUSTAINABILTY AND ETHICS IN PUBLC AND NON -PROFIT SECTORS

\title{
Acknowledgements:
}

The authors would like to thank the junior researchers who supported the phase of data collection and data entry of this study, in particular Arianna Bini and Cora Dormendo.

Access to this paper is restricted to registered delegates of the EURAM 2016 (European Academy of M anagement) Conference.
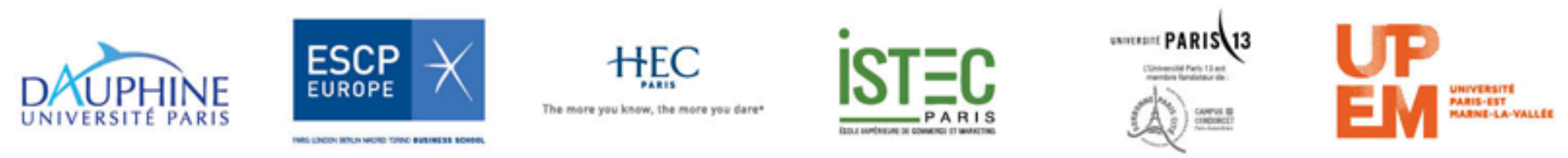

ISSN 2466-7498. 


\title{
Stakeholder engagement and public information through social media: a study of Canadian and American public transportation agencies
}

\begin{abstract}
This study uses theories on dialogic accounting to assess whether online interaction through social media is used as a mechanism of public information and stakeholder engagement by Canadian and American public transportation agencies. We embraced a quantitative methodology in which content analysis was performed on the Facebook and Twitter accounts of 35 transit operators in Canada and the United States. We categorised the contents of 1,222 Facebook posts and 2,615 tweets, assessed which level and what type of interaction was effectively reached for every category, tracked whether and how agencies reply to comments on their posts, and assessed the general tenor of the discussion. Our results show that public transportation agencies often take advantage of their presence on social media to provide the public with information on their services and to perform activities associated with stakeholder engagement. However, we have found some significant differences in the utilisation of social media by public transportation agencies, all of which are discussed in the conclusion.
\end{abstract}

Keywords: Stakeholder engagement, Social 


\title{
Title
}

\section{Stakeholder engagement and public information through social media: a study of Canadian} and American public transportation agencies

\begin{abstract}
This study uses theories on dialogic accounting to assess whether online interaction through social media is used as a mechanism of public information and stakeholder engagement by Canadian and American public transportation agencies. We embraced a quantitative methodology in which content analysis was performed on the Facebook and Twitter accounts of 35 transit operators in Canada and the United States. We categorised the contents of 1,222 Facebook posts and 2,615 tweets, assessed which level and what type of interaction was effectively reached for every category, tracked whether and how agencies reply to comments on their posts, and assessed the general tenor of the discussion. Our results show that public transportation agencies often take advantage of their presence on social media to provide the public with information on their services and to perform activities associated with stakeholder engagement. However, we have found some significant differences in the utilisation of social media by public transportation agencies, all of which are discussed in the conclusion.
\end{abstract}

\section{Keywords}

Stakeholder engagement, Social media, Dialogic accounting, Public management, Public transportation. 
Title

Stakeholder engagement and public information through social media: a study of Canadian and American public transportation agencies

\section{Introduction}

Social media applications (e.g. Facebook, Twitter, YouTube, Flickr, etc.) are enabling citizens and private/public organizations to openly and freely interact on the Web (Ma, 2014). According to the extant literature, by 2005 and 2006 accumulation strategies related to the Internet had shifted from a primary focus on information to a focus on communication and cooperation (Fuchs, 2008). Some scholars like to designate this transformation as the emergence of "Internet 2.0" or "Web 2.0." The advent of Web 2.0 not only reorganized the ways in which private and public organizations collected information, but it also redefined stakeholders' expectations. Social media, for instance, often encourages innovation and improved transparency (Meijer and Thaens, 2010; Bonsón and Ratkai, 2013) and stakeholders are recognized as partners and co-creators, not just as clients or users (Chua et al., 2012).

These new tools of dialogic communication have opened up new possibilities for public agencies to connect with their stakeholders by allowing them to receive real-time feedback on organisational announcements and engage in conversations. Although one-way communication is still the most common form of messaging strategy adopted by organisations on social media (Brainard and Edlins, 2015; Waters and Jamal, 2011; Xifra and Grau, 2010), attempts to encourage interaction between organizations and users are becoming increasingly popular (Meijer and Torenvlied, 2014; Rybako and Seltzer, 2010). A diverse array of actors in the public sector have adopted and invested in these technologies in order to guarantee timely information, improve public service quality, and encourage greater participation in various societal debates. Furthermore, social media is expected to enhance participation, learning, and knowledge production in government 
settings, challenging traditional authority boundaries (Feeney and Welch, 2014). Many transit agencies, for instance, have begun to incorporate social media into their planning, marketing, and communication strategies. Social media use is valued because it allows public transportation officials to communicate with riders, reach out to potential riders, develop stronger connections with the local community and NGOs, recruit new employees, and improve the agency's image (TCRP, 2012). Some transit agencies also use social media applications to engage in customer service activities and obtain feedback from stakeholders on services and programs.

Social media can also pose specific challenges for transit agencies, including content management and strategies for addressing online criticism, estimating resource requirements (particularly staffing) for managing these applications, and developing techniques to measure their costs and benefits. Furthermore, organizations must ensure that social media applications are accessible to people with disabilities or people who don't have ready access to smart phones and high-speed Internet. Agencies also have to manage legal and security concerns, including online security, privacy protections, and complying with requirements for transparency and records retention.

Three factors help explain the adoption of social media by transit agencies:

- Public information - providing the public with information about services, fares, long-range planning projects, and all timely updates in order to share real-time service information and advisories with their riders;

- Stakeholder and public engagement - taking advantage of the interactive aspects of social media to connect with their customers, employees (e.g. recognizing current workers and recruiting new employees), and local communities in an informal way;

- Entertainment and other ancillary functions - entertaining their riders through songs, videos, and contests, and establishing a rapport with users and stakeholders.

In 2012 the Transit Cooperative Research Program (TCRP) explored the use of social media among 
American and Canadian transit agencies. The TCRP study highlights some aspects of social media use that require additional research. For instance, although industry experts believe that having a social media policy is critical, a majority of transit agencies have no such policy in place.

Furthermore, most of the agencies in the TCRP study measured the effectiveness of their social media activities by using built-in metrics, such as counting "friends" or followers and using thirdparty applications such as Google Analytics (TCRP, 2012). Questions arise as to whether social media platforms can bridge the digital divide, the perceived gap between people who have access to information technology and those who do not. Finally, some experts have identified the various revenue-creation opportunities associated with these applications, especially location-based technologies and social-buying services.

We decided to study the Facebook and Twitter pages of the same 35 transit agencies that were examined in the TCRP study. This was done in order to understand the level of interaction especially stakeholder and public engagement and public information - of Canadian and American transit agencies. Unfortunately, scholars have not focused much energy towards understanding why public transportation agencies adopt social networking tools (Li and Feeney, 2014). We will fill this gap in the public management literature by employing theories on dialogic accounting, many of which have been embraced by scholars in recent years (see, for example, Dillard and Ruchala, 2005; Bebbington et al., 2007a; Brown, 2009; Brown and Dillard, 2013a, 2013b).

Our exploratory research question involves determining whether or not online interaction through social media represents an effective mechanism of public information and stakeholder engagement in terms of improving the quality of transportation services and encouraging citizen participation (Bebbington et al., 2007b). In the process of answering this question we will:

- investigate the role of social media in the context of New Public Service and New Public Governance ideologies and the specific contribution of web 2.0 in creating a model of authentic dialogic accounting and interaction; 
- conduct a content analysis of the Facebook and Twitter pages of several transit agencies in the United States and Canada, with specific reference to the functions of public information and stakeholder engagement;

- reach a conclusion on the contribution of social media in the context of American and Canadian public transportation agencies, highlighting the limits of the present research and avenues for future research.

\section{Theoretical framework}

Social media has become one of the most important instruments of public engagement and information in recent years (see, for example, Kent et al., 2003; Park and Reber, 2008; Porter, 2001; Rybako and Seltzer, 2010; Unerman and Bennett, 2004). Online social media can be defined as " $a$ group of Internet based applications that build on the ideological and technological foundations of Web 2.0, and that allow the creation and exchange of User Generated Content" (Kaplan and Haenlein, 2010 , p. 61; see also: Cormode \& Krishanmurthy, 2008). It is basically an umbrella term describing different types of applications, such as collaborative projects (e.g. Wikipedia), blogs/micro-blogs (e.g. Twitter), content communities (e.g. YouTube), social networking sites (e.g. Facebook), virtual game worlds (e.g. World of Warcraft), and virtual social worlds (e.g., Second Life) (Kaplan and Haenlein, 2009; Kaplan and Haenlein, 2012). Social media applications are particularly well-suited for public information and stakeholder engagement, as they make it possible to interact with a large group of people, especially users, employees, NGOs, and local communities. Users are no longer the passive consumers of content; they have become co-creators of a virtual public arena in which sharing ideas, opinions, pictures, videos, web links, and other content is commonplace (Bekkers, 2013). Social media also allows organizations and individuals to exploit people, information, and data sources that are present on the Internet by bringing them together to address specific goals or problems. The challenge is to bring these diverse perspectives together so 
that new ideas and perspectives can emerge (Surowiecki, 2004), a task that has been made easier in recent years due to the emergence of smartphones, tablets, and notebooks. Users now have instant access to information, oftentimes in a wholly transparent manner (Bekkers, 2013, p. 255). Of course, social media doesn't always serve as a neutral communication tool for public service providers because goals and actual results don’t always converge (Bekkers and Homburg, 2007). This is due to the fact that public service providers often have aims that are rather specific and context driven, resulting in a host of unintended consequences (Dawes, 2008).

This study explores the utilization of social media - most notably Facebook and Twitter - as a means of dialogic conversation among various public transportation agencies and their stakeholders (Swift et al., 2001; Lovejoy et al., 2012). Emphasis will also be placed on the opinions and expectations of stakeholders, even when they diverge from the organisation's point of view. We study the value of Facebook and Twitter in terms of creating democratic debate (Unerman and Bennett, 2004) on a wide array of topics, including grant-making policies, programme funding, and social responsibility issues. We also look at how social media activities help these organizations better define their short and long term strategies and spread information among the citizenry.

In the public transportation sector, crowd sourcing plays an important role in terms of generating ideas on transit planning (Brabham, 2008; Pfeffer and Salancik, 1978; Kraemer and King, 1986). In other words, social media is a powerful tool for reaching out to a large number of stakeholders, thus creating authentic dialogic (between stakeholders and the organization) or polylogic (among the stakeholders themselves) accounting systems (Dillard and Ruchala, 2005; Bebbington et al., 2007a; Brown, 2009, Brown and Dillard, 2013a, 2013b) based on a democratic but not necessarily convergent - consultation of public opinion. Thus, according to Greve (2015), social media allow citizens to influence important policy debates.

Recent studies in the field of public administration suggest that citizen participation through e-government and collaboration between government and citizen are contributing to the creation of 
a New Public Service (NPS) that stands in stark contrast to older ideas on public administration and the New Public Management (NPM) movement. Information technology (IT) has played a key role in many of the studies that emerged during the 1990s and early-2000s (Hood, 1991; Barzelay 2001; Christensen and Lægreid 2011; OECD, 2010). Unfortunately, it was almost always seen as just one element out of many and was only partially incorporated in the larger theoretical framework. For instance, Dunleavy et al. (2006a and b) understood digitalization as being something more than just a support tool for NPM or a simple process of institutionalization of IT (Fountain, 2001): they began to view e-government as a possible alternative to NPM, characterized with a recentralization of decision process and service providing, which is able to reduce costs for public administrations and waiting times for citizens (Dunleavy et al. 2006a). E-government, in fact, has the potential to allow more user-based/need-based reorganization, digitalization of processes, and open-book decision making (Bretschneider, S. I., \& Mergel, I., 2010).

Some authors claim that social media has further expanded the potentialities of egovernment by contributing to a higher level of interaction between citizens and public service providers (Greve, 2015; Mergel 2012). According to Denhardt and Denhardt (2003), the increase in public interest is often the result of a dialogue about mutual or overlapping interests. In the NPS approach, the government acts as a brokering interest among citizens and other groups so as to create shared values and build coalitions of public, private, and non-profit agencies to meet mutually agreed upon needs. This approach to accountability is based on the assumption that public servants must attend to legal matters, community values, political norms, professional standards, and citizen interests.

Social media can also promote a governance framework based on democratic citizenship (Box, 1998; Evans and Boyte, 1986; King and Stivers, 1998; Mansbridge, 1994; Sandel, 1996) and the participation of local communities and civil society (Etzioni, 1988, 1993; Putnam, 2000) in contrast with the NPM that is deeply rooted in rational and public choice theory (Ostrom and 
Ostrom, 1971; Simon, 1957). NPS, in fact, is based on the assumption of democratic motivations for participating in the public sphere (Denhardt and Denhardt, 2003, p. 30) while the NPM perspective views public interest as a by-product of the pursuit of private interests in which the state is expected to act as a facilitator of individual choice using market techniques (Brainard and McNutt, 2010, p. 838). Social media stimulates the dialogue among citizens (rather than among users or customers) and between communities and the public administration, facilitating greater participation and collaboration among the citizenry rather than merely implementing preconceived programs in a top-down process (Brainard and McNutt, 2010, p. 839).

However, there are some aspects of social media that are capable of altering the relationship between politicians and public managers, and public managers and citizens (Landsbergen and Park 2011; Mergel 2012). In the public transportation sector, in particular, the use of social media has interesting implications in terms of citizen/user participation, public information about transit problems, fares, and long-term projects, employee recognition, and even entertainment (Transit Cooperative Research Program, 2012).

Another possible issue linked to the use of social media in public agencies involves "publicmaking" (Newman and Clarke, 2009), a process that seeks to address the divergence of opinion among different publics and "new groups" of citizens. Since different groups of people require different services, public transportation agencies often face huge challenges in meeting the needs of a diverse citizenry (Farazmand, 2012). In many respects, the challenges of pluralism complement the New Public Governance (NPG) approach. According to Osborne (2010), NPG "is rooted firmly within organizational sociology and network theory and acknowledges the increasingly fragmented and uncertain nature of public management in the twenty-first century" (Haveri, 2006). Osborne supports the idea of a pluralist state, where multiple processes inform the policy making system and many inter-dependent actors agree to deliver public services. NPG focuses on inter-organizational relationships and governance, underlining the necessity of improving service effectiveness and 
outcomes. The design and evaluation of inter-organizational relationships is crucial to governing the entire process, especially when it comes to building trust and relational capital (Bovaird, 2006; Greve, 2015; Teicher et al., 2006). Together with other instruments, social media can help build coalitions and facilitate collaboration between private, public, and non-profit entities.

However, social media's value in terms of conducting stakeholder engagement often depends on the concept of stakeholder engagement itself. It is necessary to point out, in fact, that stakeholder engagement and stakeholder management are two distinct processes (Clarkson, 1995, pp. 92-117; Svendsen, 1998; Waddock, 2002). On the one hand, stakeholder management foresees to manage stakeholders' expectations and the claims they support in accordance with their salience (Mitchell et al., 1997), also balancing these various positions (O'Dwyer, 2005); on the other hand, the stakeholder engagement implies that organisations try to engage primary stakeholders in decisionmaking processes, making them participants in organisation management, sharing information, dialoguing, and creating a model of mutual responsibility. According to Andriof et al. (2002, p. 9), stakeholder engagement "creates a dynamic context of interaction, mutual respect, dialogue and change, not a unilateral management of stakeholders." As a result, the main feature of stakeholder engagement is not to encourage the mere involvement of stakeholders to "mitigate" or manage their expectations, but to create a network of mutual responsibility (Andriof et al., 2002, p. 15; Manetti, 2011; Unerman and Bennett, 2004; Voss et al., 2005; Windsor, 2002, p. 138) in which stakeholders are able to interact each other.

Stakeholder and citizen engagement is conducted in order to attain two forms of interaction or dialogic communication:

1. a deliberative, general consensus (Laughlin, 1987 and 2007) based on Habermas' "ideal speech situation" - a communication among stakeholders in undistorted conditions (Habermas, 1984, 1987, 1989) that can be built in a "public sphere," "a discursive arena that is home to citizen debate, deliberation, agreement and action" (Villa, 1992, p. 712; 
Dahlberg, 2005) - on what information and data should be disclosed in the report. When applied to the corporate arena, the result of "an open, honest and unbiased ideal speech situation debate among all stakeholders should therefore lead to the acceptance by all stakeholders of a democratically determined consensus view of corporate responsibilities" (Unerman and Bennett, 2004, p. 691).

2. a collection of divergent socio-political views in an agonistic perspective, highlighting the unavoidable values and assumptions associated with different accounts and recognizing the need for multiple engagements between different actors across various political spaces (Gray, 2002; O’Dwyer, 2005; Brown and Dillard, 2013a and 2013b). This perspective recognizes the need for multiple engagements between different actors across various political spaces (Gray, 2002; O’Dwyer, 2005) based on an agonistic model of democratic participation (Brown, 2009; Dillard and Roslender, 2011; Dillard and Brown, 2012; Brown and Dillard, 2013 a, 2013b).

In the democratic deliberative approach, stakeholder engagement is necessary for defining the general consensus among diverse stakeholders. Proponents of the agonistic approach, meanwhile, suggest that stakeholder engagement helps synthesize the different points of views found among groups that have a diversity of interests.

In this study, we want to determine whether public transportation agencies use social media for spreading public information and conducting stakeholder engagement, using these Internetbased tools as a sort of "public arena." We also want to determine whether these organizations use social media as a means of recognizing diverse ideas and points of view in an agonistic perspective. Of course, dialogic approaches can be criticized due to the practical difficulties in creating the appropriate conditions for success (Power and Laughlin, 1996). Even the most significant difficulties and obstacles associated with dialogic processes, such as the impracticability of all stakeholders taking part in a dialogue (Power and Laughlin, 1996) or the impossibility of balancing 
divergent stakeholder expectations, can be alleviated, if not solved, using social media. Indeed, social media can contribute to the improvement of public information and public accountability, providing accountability systems with the opportunity to significantly change the behaviour of both organizations and stakeholders (Unerman and Bennett, 2004).

Nevertheless, social media can also be used as powerful instruments of legitimization (Bonsón and Ratkai, 2013) rather than a means of creating authentic dialogue and cooperation. Legitimacy theory suggests that a social contract exists between individual organizations and society (Deegan, 2002; Deegan, 2006; Suchman, 1995). This means that an organization can conduct its activities in a manner that is both socially acceptable and does not necessarily follow stakeholders' expectations. Thus, organisations can voluntarily report and communicate over social media according to the expectations of society (Pfeffer and Salancik, 1978). Scholars who buy into the legitimacy perspective suggest that organizations use these instruments of external accountability to influence (or even manipulate) stakeholder perceptions (Patten and Guidry, 2010; Coupland, 2007; Deegan, 2002), to reduce their external costs, and diminish pressures being imposed by society or regulators (Tate et al., 2010; Caron and Turcotte, 2009; Ballou et al., 2006; Adams, 2002). Voluntary information is disclosed for strategic reasons rather than on the basis of any perceived responsibilities. Voluntary disclosure through social media can thus enhance an organization's legitimacy, elevating its image and perception among various members of society and external stakeholders, especially when using external accountability systems (Clarkson et al., 2011). This has led scholars to question whether social media is used by organizations for legitimizing their presence within society and changing their reputation among stakeholders or rather for creating a system of dialogic - although not necessarily convergent - debate on public issues.

We hope to add to the literature on public services by determining whether social media especially Facebook and Twitter - act as reliable instruments of public information and citizen 
engagement in public transportation agencies, or whether they are just another mechanism of legitimization. We believe that the literature is lacking in terms of the role social media plays among public services, thereby revealing a gap in knowledge that hinders the development of such studies and their empirical applications.

\section{Methodology}

In order to answer our exploratory research question, we opted for a quantitative methodology based on content analysis, a research technique based on the objective, systematic, and quantitative description of the manifest content of communication (Berelson, 1952). Content analysis is a flexible approach to the examination of various media, documents, and texts, one that seeks to quantify content in terms of predetermined categories and in a systemic and replicable manner (Bryman and Bell, 2015).

We analysed the Facebook and Twitter account of 35 transit operators in the United States and Canada, all of which figured prominently in a report published by the Transit Cooperative Research Program in 2012 (TCRP, 2012). This sample represents 18 U.S. states, the District of Columbia, and five Canadian provinces (see Table 1 for details).

Insert TABLE 1 here

Most agencies (80\%) are located in large metropolitan areas, which is defined as urban areas that have a population of 200,000 or more; $17 \%$ are in small urban areas (population $50,000-200,000$ ); and one agency (3\%) is located in a rural area (TCRP, 2012). All transit modes are represented, 
including rail, bus, vanpool, demand-response, and ferry. Annual ridership ranges from fewer than 500,000 trips to more than 2 billion (TCRP, 2012).

We focus on Facebook and Twitter because they are the most popular social media among public transit organizations. The unit of data collection for the content analysis of Facebook consists of each post generated by the organisation on its official page. The unit of data collection for Twitter, meanwhile, consists of each original tweet generated by the organisation. Some agencies have more than one Twitter account. For instance, Dallas Area Rapid Transit uses@dartmedia as its general account, but also uses@dartalert for alerts. Similarly, the Toronto Transit Commission uses@TTCnotices as a general account, but also@TTChelps for customer service. Whenever this situation arose, we analysed the general account. We studied posts and tweets that were published between May 1st, 2015, and June 30th, 2015, with a limit of 100 posts and 100 tweets per organisation.

The research team was composed of five members: two academic supervisors, a coordinator of the content analysis, and two scholars with proficiency in English. Some tests were conducted in order to highlight ambiguous or unclear interpretation of the coding rules; the results were compared and the differences of interpretation were discussed. This resulted in a final set of detection and classification rules for posts and tweets. Given the vast amount of data at our disposal, we decided to divide the actual content analysis among various team members. All in all, our team analysed 1,222 Facebook posts and 2,615 tweets, as well as all the comments and replies to these posts and tweets. Afterwards, the supervisors and the coordinator compared the results obtained by the other members in order to ensure that there were no differences of interpretation; we obtained a Cohen's kappa coefficient of inter-reliability of 0.8 .

The first step of our content analysis was to categorise the content of each post/tweet in one of the following categories:

- Public information (coded as $P I$ ): posts or tweets providing the public with information 
about services, fares, long-range planning projects, and timely updates that share real-time service information and advisories with their riders (e.g. info about delays and disruptions).

- Stakeholder and public engagement $(S E)$ : posts or tweets that attempt to connect with the organization's customers, employees (e.g. recognizing current workers and recruiting new employees), and local communities in an informal way (e.g. customer suggestions for new services). For this specific category we also assessed which type of stakeholder shareholders/investors, employees, suppliers, customers/end users, state/public administration, third sector organizations/NGOs, and community/general - was engaged.

- Entertainment and other ancillary functions $(O)$ : a residual category for posts and tweets that sought to create a rapport with riders (e.g. Christmas greetings or online prize competitions) or entertain them through songs, videos, and contests.

Secondly, we assessed what level and what type of interaction was effectively reached for every category of post and tweet. We collected the number of likes, shares, and comments (for Facebook accounts) and favourites, retweets, and replies (for Twitter accounts) for every single unit in each category. This is relevant because a high number of likes/favourites, sharing/retweets, and replies/comments suggests a reasonable level of interaction between agencies and users.

Since we want to assess the contribution of social media to SE in a system of dialogic accounting, we also tracked whether (and how) agencies reply to comments on their posts, thereby creating a true two-way conversation with users, and whether users communicate with each other on the organisation's Facebook or Twitter page. In order to do this, we defined two "interaction ratios." The first interaction ratio - "Interaction ratio (agency)" - varies between 1, when the organisation replied to at least one comment (Facebook) or replied (Twitter) in every post, and 0, when the organisation did not reply to any comment/tweet. The second interaction ratio "Interaction ratio (users)" - varies between 1, when at least one user replied to at least one other user comment (Facebook) or replied (Twitter) in every post, and 0, when users did not reply to any 
comment/tweet. This analysis was carried out in order to understand how often local transportation agencies take part in two-way discussions and assess the extent to which users interact with each other.

In addition, we also investigated every comment/reply in order to assess the general tenor of the discussion. In particular, we wanted to determine if feedback from users was more positively oriented (compliments for the agency's activities, constructive proposals, etc.), negatively oriented (protests, constructive criticism, etc.), or neutral. In this fourth step, we classified each comment/reply with a value ranging from 1 (protest) to 5 (compliment). Comments with constructive criticism received a value of 2 , constructive proposals received a value of 4 , and neutral comments received a value of 3 . We then proceeded to build an index for every category of units that showed the average tone of comments, using a scale of 1 to 5 . All of the data was collected into two databases, one for Facebook posts and one for Twitter tweets. Spam and off-topic comments were excluded from the analysis.

\section{Results}

We determined that 33 agencies out of 35 have an active Facebook page that features at least one post in the period of our analysis, and 32 out of 35 have an active Twitter account. Table 1 shows the amount of posts and tweets published by each operator on its official Facebook page and Twitter account between May 1st, 2015, and June 30th, 2015 (with a maximum of 100 posts and 100 tweets per organisation). Table 1 also shows the average number of likes, shares, and comments on the Facebook posts included in our analysis, as well as the average number of favourites, retweets, and replies to tweets. Since the first part of our analysis focused on determining if social media is used as a mechanism of public information and stakeholder engagement, we categorised the posts according to their aim and content. Table 2 shows the results of the content analysis on a total of 1,222 posts and 2,615 tweets. 
Insert TABLE 2 here

In order to answer our exploratory research question, we need to understand what public transportation agencies hope to accomplish by using social media. During the period of analysis, organisations in our sample published 304 Facebook posts $(24.88 \%$ of the total Facebook posts) with the aim of engaging one or more of their stakeholders (SE posts). 427 Facebook posts (34.94\%) provided public information (PI posts), including information about services, real-time updates, or disruptions. SE and PI posts on Facebook accounted for 59.82\% of total posts; posts on entertainment and other ancillary functions $(\mathrm{O})$ accounted for the remaining $40.18 \%$. In terms of Twitter usage, 452 tweets (17.28\%) were aimed at stakeholder engagement and 1621 (61.99\%) were aimed at issuing public information. SE and PI tweets accounted for $79.27 \%$ of total tweets, while tweets labelled as 0 accounted for the remaining $20.73 \%$. Twitter appears to be more focused on PI and SE than O. Table 3 shows an example of a Facebook post that features stakeholder engagement. Table 4 shows a tweet that contains public information on services (texts are reported as is, including typos, but user identities and pictures have been removed for anonymity).

Insert TABLE 3 here

Insert TABLE 4 here 
These results show that public transportation agencies often take advantage of their presence on social media to provide the public with information on their services and perform activities involving stakeholder engagement. As Table 2 shows, posts and tweets aiming at stakeholder engagement are generally targeted towards customers, end users, or the community as a whole.

However, our results show some significant differences in terms of how these two social media are utilized. Twitter is mainly used for PI messages, especially short, real time updates on services, delays, or disruptions. Both Facebook and Twitter are used for SE activities, but the former appears to be used more than the latter to interact with stakeholders in a dialogic perspective. Standard deviation values confirm that there are differences in the sample in terms of how public transportation agencies approach social media. Regardless, we can confirm, with a few exceptions, that these types of organisations have an active presence on Facebook and Twitter and regularly publish new content. Although the willingness to engage stakeholders may vary across the sample, nearly all of the organisations published at least one Facebook post on SE and one tweet on PI in the period of analysis.

This trend is confirmed by data on online interaction and conversations collected during the second and third step of our content analysis. Table 5, which shows social media data on interaction through Facebook posts (Panel A) and tweets (Panel B), illustrates the extent to which Facebook produced a higher grade of interaction. The total and average values of likes, shares, and replies are notably higher on Facebook, thus confirming the notion that users are less likely to interact with public transportation agencies on Twitter. An average value of 24.67 likes, 17.66 shares, and 4.98 comments were found in Facebook posts that were categorised as SE. Tweets devoted to SE, meanwhile, collected an average value of 1.07 favourites, 1.21 retweets, and 0.38 replies. This ratio is roughly the same for Public Information (PI) messages: Facebook has an average value of 25.91 likes, 4.47 shares, and 3.94 comments, while Twitter received an average value of 1.01 favourites, 
2.23, retweets and 0.44 replies. Facebook posts categorised as $\mathrm{O}$ received an average value of 51.67 likes, 6.46 shares, and 4.36 comments; tweets in the same category collected an average value of 3.02 favourites, 2.29 retweets, and 0.46 replies. Posts and tweets on entertainment and other ancillary functions $(\mathrm{O})$ present the highest level of likes and favourites. We can conclude, then, that interaction is higher on Facebook and is more likely to feature content that tries to engage stakeholders. Conversely, Twitter tends to focus on messages containing PI. We can affirm that public transportation agencies often use social media to engage stakeholders and publish public information, albeit in ways that vary according to which type of social media is being used.

Insert TABLE 5 here

The behaviour of users and organisations are different on Facebook and Twitter, especially if we take levels of interaction into account. Our content analysis assessed the level and type of interaction between public transportation agencies and users for each category of posts on Facebook and Twitter. In the third and fourth step of our analysis, we also investigated the tenor of these comments and the extent to which the organisations in our sample replied to user comments. This is important because it helps us understand if social media actually supports a system of dialogic accounting for public transportation agencies, and whether they lead to two-way conversations between organisations and their stakeholders. Table 6 shows the number of Facebook posts with comments (Panel A) and tweets with replies (Panel B), two indexes representing the level of interaction between agencies and users and among users, and an index describing the tenor of comments. 
Insert TABLE 6 here

Since we intend to examine the contribution of social media to SE and PI in a framework of dialogic accounting, we also studied whether public transportation agencies create two-way conversations with users and whether users communicate with each other. The interaction ratios presented in Table 6 indicate if (and how) organisations reply to comments on their official accounts. On Facebook, SE posts present a "users interaction index" of 0.464 (meaning that users replied to other users' comments in $46 \%$ of cases) and an "agency interaction index" of 0.429 (meaning that agencies replied to at least one user's comment in $43 \%$ of posts). PI posts, meanwhile, feature an interaction index for users of 0.443 and an interaction index for agencies of 0.424. These values confirm that interaction on Facebook is higher than on Twitter and that users and agencies often engage in two-way conversations. In fact, organisations in our sample effectively took part in conversations - answering users' contributions - in nearly half of posts that were published with the aim of engage users and stakeholder.

The interaction dynamic is completely different on Twitter, where SE tweets present an interaction index for users of 0.077 and an interaction index for agencies of 0.308 . Similarly, PI tweets feature an interaction index for users of 0.067 and an interaction index for agencies of 0.231. The interaction within users is much lower on Twitter than on Facebook. It is interesting to note, however, that the total agency interaction index $(0.231)$ is considerably higher than the total user interaction index (0.073), thereby showing that public transportation agencies respond to user comments and start a conversation in $23 \%$ of cases. This number rises to $30 \%$ when we look 
exclusively at tweets that are geared towards SE. Indeed, SE-related content tended to produce higher interaction values on both Twitter and Facebook.

We also wanted to determine if feedback from users is positively oriented, negatively oriented, or neutral. In order to assess the general tenor of the discussion, we examined the contents and tone of each Facebook comment or Twitter reply and built an index - ranging from 1 (critical) and 5 (supportive) - following the procedure described in Section 3. We found that the average tenor of comments to posts published by public transportation agencies is mildly negative. As Table 6 shows, Facebook posts related to SE and PI present a value of 2.829 and 2.724; tweets related to SE and PI, meanwhile, feature a value of 2.897 and 2.306. We noted a prevalence of critical comments — especially on Twitter — with regards to the general quality of the services, lines disruptions, or delays. Facebook posts on amusement and other ancillary functions $(\mathrm{O})$ present the best tenor of comments index (3.172).

An analysis of the values in this index can help us understand if the interaction produced by these organisations is geared towards generating a generic consensus necessary to achieve decisionmaking power that is shared between all stakeholders (Laughlin 1987, 2007; Habermas, 1984, 1987, 1989), or if a divergent and agonistic perspective, which highlights struggles and differences between actors, prevails (Gray, 2002; O’Dwyer, 2005; Brown and Dillard, 2013a and 2013b). Since the median value of 3 indicates a neutral/mixed tenor, we interpret average values of the tenor of comments index lower than 3 as evidence of an agonistic approach. However, we believe it is necessary to assume a cautious position, as we are dealing with agencies delivering critical local transportation services whose activities are likely to result in significant expressions of dissent, especially in the case of conversations involving disruptions and delays.

We also noted that transportation agencies operating in smaller communities usually received more appreciative posts and tweets (low interaction index but higher tenor index). Agencies serving bigger communities, conversely, face more mixed feedback and conversations are 
both more interactive and less focused. In fact, it is quite common to see heated discussions on the pages of bigger organisations, as well as more instances of spam.

\section{Conclusions}

The present research examined whether online interaction through social media is used as a mechanism of public information and stakeholder engagement by public transportation agencies. Using dialogic accounting theory as a point of reference, we conducted a content analysis on the Facebook and Twitter pages of 35 Canadian and American transit agencies.

Social media technology represents a new way for organisations and public agencies to connect and collaborate with their users and stakeholders (Brainard and Edlins, 2015). Social media is often used by local governments in hopes of improving the delivery of services to citizens and encouraging civic engagement and participation (Holzer \& Manoharan, 2008). While it is important to understand the use of technology to improve efficiency in public organizations, it is increasingly important to understand the ways in which different types of digital technologies are shaping government behaviour and why some governments adopt some technologies and not others (Li and Feeney, 2014).

Building on these premises, our results confirm that many public transportation agencies have an active presence on Facebook and Twitter. The results of our content analysis show that organisations in our sample often take advantage of social media to provide public information on their services and engage stakeholders. However, our analyses also show some significant differences in how Facebook and Twitter are employed. Twitter, for instance, is most often used for Public Information messages, especially short, real time updates on services, delays, or disruptions. Both social media are used for messages engaging stakeholders, but Facebook appears to be used more than Twitter to publish content aiming at interacting in a dialogic perspective and creating two-way conversations with users. Dialogic accounting is not only the collection of data through 
the dialogue with stakeholders, but also a means of fostering democratic interaction. Social media might help us embrace more dialogic forms of accounting, a notion that is supported by much of the data in the current study. For instance, the higher total and average values of likes, shares, and replies on Facebook confirm that users prefer to interact with public transportation agencies on this social media than on Twitter. Interaction is higher and focused on Facebook, especially with regards to content that tries to engage stakeholders. Twitter, meanwhile, features lower levels of interaction and is most often focused on public utility information. If we take the levels of interaction into account, we can then confirm that the behaviour of both public transportation agencies and the social media users who visit their pages are different on Facebook and Twitter, as both take advantage of the peculiar characteristics of each type of social media.

Our findings regarding interaction levels show that users and agencies are often actively engaged in two-way conversations on Facebook, as public transportation agencies often reply to users and users often reply to each other. This led us to conclude that interaction on social media can act as a valid tool for stakeholder engagement and dialogic accounting, allowing organizations to collect relevant information from stakeholders. It is important, however, to recognize that social media can also be used to support traditional management accounting systems because they result in the collection of more and better information from various stakeholders. Thus, social media constitutes an effective instrument of dialogic accounting because they help better define materiality and relevance of information.

Nonetheless, we believe that social media's potential has not yet been fully exploited for at least two reasons. Firstly, the emergence of social media is a relatively new phenomena and organisations still need to learn the best way to manage them, especially if they want to use them for something more than simply promoting a service or a product. Secondly, and perhaps most importantly, many organizations are not fully aware of the diversity of stakeholder values and 
interests. In other words, our results confirm that organisations are slow to adopt a pluralist vision that might expose them to divergent values and interests.

The results of our study on the tenor of comments on Facebook and Twitter can help us understand if the interaction encouraged by public transportation agencies is oriented towards the generation of a consensus necessary to achieve the type of decision-making power that is shared between all stakeholders (Laughlin 1987, 2007; Habermas, 1984, 1987, 1989), or if a divergent and agonistic perspective, which highlights struggles and differences between actors, prevails (Gray, 2002; O'Dwyer, 2005; Brown and Dillard, 2013a and 2013b). The data we collected on Facebook and Twitter led us to argue in favour of the latter. This is not surprising, as we are dealing with organisations that deliver critical transportation services and whose actions are likely to result in significant expressions of dissent, especially in conversations that revolve around service disruptions or delays.

Nonetheless, there are some significant differences between the types of comments found on Facebook and those found on Twitter. Given the different features of Facebook and Twitter, and the different types of content posted on each social network, our results show that Facebook has a more deliberative approach and Twitter a more agonistic perspective. Facebook is more flexible and more capable of giving space to complex commentary, while Twitter enables rapid and short responses. Our results also show that Facebook pages are sometimes used as public arenas that sustain democratic conversations, focusing not only on the interaction between organisations and stakeholders but between users and stakeholders themselves. Interaction values confirm that Facebook users often show a willingness to interact with other users, oftentimes to help other users answer a question or confirm a complaint by other customers. As a result, transportation agencies are given the opportunity to observe and analyse user behaviour and make any necessary adjustments. 
The current study has at least two limitations that ought to be addressed in future studies. Firstly, future research should make an effort to provide in-depth case studies on how organizations invest in social media interaction, manage their profiles and mobile apps, and use the data collected on social media to change their strategies. Secondly, this research focuses solely on Canadian and American organisations. Future studies should expand into different geographical areas.

In terms of its practical implications, this study helps shed light on the utilization of social media by public transportations agencies, thereby drawing more attention to how innovative technologies can be used in the future to engage users and stakeholders in both the public and private sector. 


\section{References}

Adams, C. (2002). Internal organisational factors influencing corporate social and ethical reporting: Beyond current theorizing. Accounting, Auditing \& Accountability Journal, 15(2), 223-250.

Andriof, J., Waddock, S., Husted, B. \& Rahman, S. (2002). Unfolding Stakeholder Thinking: Theory Responsibility and Engagement. Sheffield: Greenleag Publishing.

Ballou, B., Heitger, D.L., \& Landes, C.E. (2006). The future of corporate sustainability reporting: A rapidly growing assurance opportunity. Journal of Accountancy, 22(3), 5-74.

Barzelay, M. (2001). The New Public Management. Berkeley: University of California Press.

Bebbington, J., Brown, J. \& Frame, B. (2007a). Accounting technologies and sustainability assessment models. Ecological Economics, 61(2/3), 224-236.

Bebbington, J., Brown, J., Frame, B. \& Thomson, I. (2007b). Theorizing engagement: the potential of a critical dialogic approach. Accounting Auditing and Accountability Journal, 20(3), 356-381.

Bekkers, V. (2013). E-government and innovation: the socio-political shaping of ICT as a source of innovation, in Osborne S. and Brown L. (Eds.), Handbook of innovation in public services, Cheltenham: Edwar Elgar, 253-268

Bekkers, V., \& Homburg, V. (2005). E-government as an information ecology. In V. Bekkers and V. Homburg (Eds), The information Ecology of E-Government, Amsterdam: IOS Press, 1-19.

Berelson, B. (1952). Content analysis in Communication Research. New York: Free Press.

Bonsón, E. \& Ratkai, M. (2013). A set of metrics to assess stakeholder engagement and social legitimacy on a corporate Facebook page. Online Information Review, 37(5), 787-803.

Box, R. (1998). Citizen Governance. Thousand Oaks, CA: Sage Publications, Inc.

Brabham, D. (2008). Crowdsourcing as a model for problem solving: an introduction and cases convergence. International Journal of Research into New Media Technologies, 14(2), 75-90.

Brainard, L., \& Edlins, M. (2014). Top 10 US Municipal Police Departments and Their Social Media Usage. The American Review of Public Administration, 45(6), 728-745.

Brainard, L., \& McNutt, J. G. (2010). Virtual government-citizen relations: Informational, transactional, or collaborative?. Administration \& Society, 42(7), 836-858.

Bretschneider, S. I., \& Mergel, I. (2010). Technology and public management information systems: Where have we been and where are we going. In D. C. Menzel, \& H. J. White (Eds.), The state of public administration: Issues, problems and challenges, 187-203. New York: M.E. Sharpe, Inc. 
Bryman, A. \& Bell, E. (2015). Business research methods. New York: Oxford University Press.

Brown, J. \& Dillard, J. (2013a). Agonizing over Engagement: Social and Environmental Accounting and the 'Death of Environmentalism' Debates. Critical Perspectives on Accounting, 24(1), 1-18.

Brown, J. \& Dillard, J. (2013b). Critical accounting and communicative action: On the limits of consensual deliberation. Critical Perspectives on Accounting, 24(3), 176-190.

Brown, J. (2009). Democracy Sustainability and Dialogic Accounting Technologies: Taking Pluralism Seriously. Critical Perspectives on Accounting, 20(3), 313-342.

Caron, M. \& Turcotte, M.B. (2009). Path dependence and path creation: Framing the extra-financial information for the sustainable trajectory. Accounting, Auditing \& Accountability Journal, Vol. 22 No. 2, pp. 272-297.

Christensen, T., \& Lægreid, P. (Eds.). (2011). The Ashgate Research Companion to New Public Management. Aldershot: Ashgate.

Chua, A.Y.K., Goh, D.H. \& Ang, R.P. (2012). Web 2.0 applications in government websites: prevalence, use and correlations with perceived website quality. Online Information Review, 36(2), 175-195.

Clarkson P.M., Overell, M.B. \& Chapple, L. (2011). Environmental Reporting and its Relation to Corporate Environmental Performance. Abacus, 47(1), 27-60.

Clarkson, M. B. E. (1995). A Stakeholder Framework for Analyzing and Evaluating Corporate Social Performance. Academy of Management Journal, 20(1), 92-118.

Cormode, G., \& Krishanmurthy, B. (2008). Key differences between Web 1.0 and Web 2.0. First Monday - Peer Reviewed Journal of the Internet, 13(6), 1-19.

Coupland, C. (2007). Corporate social and environmental responsibility in web-based reports: Currency in the banking sector. Critical Perspectives on Accounting, 17(7), 865-881.

Dahlberg, L. (2005). The Habermasian public sphere: Taking difference seriously?. Theory and Society, 34(2), 111-136.

Deegan, C. (2002). The legitimising effect of social and environmental disclosures. A theoretical foundation. Accounting, Auditing \& Accountability Journal, 15(3), 282-311.

Deegan, C. (2006). Legitimacy theory, in Hogue, Z. (eds), Methodological Issues in Accounting Research: Theories and Methods. London: Spiramus Press, 161-182. 
Denhardt R.B. \& Denhardt J.V. (2003), The New Public Service: An Approach to Reform. International Review of Public Administration, 8(1), 3-10

Dillard, J. \& Brown, J. (2012). Agonistic pluralism and imagining CSEAR into the future. Social and Environmental Accountability Journal, 32(1), 3-16.

Dillard, J. \& Roslender, R. (2011). Taking pluralism seriously: Embedded moralities in management accounting and control systems. Critical Perspectives on Accounting, 22(2), 135-147.

Dillard, J. and Ruchala, L. (2005). The rules are game: from instrumental rationality to administrative evil. Accounting Auditing and Accountability Journal, 18(5), 608-630.

Dunleavy, P., et al. (2006a). New public management is dead. Long live digital Era governance. Journal of Public Administration Research and Theory, 16, 467-497.

Dunleavy, P., et al. (2006b). Digital Era Governance. Oxford: Oxford University Press.

Etzioni, A. (1993). The spirit of community: The reinvention of American society. New York: Simon and Schuster.

Etzioni, A. (1988). The Moral Dimension: Towards a New Economics. New York: Free Press.

Evans, S., and Boyte, H. (1986). Free Spaces: The Sources of Democratic Change in America. New York: Harper and Ro.

Farazmand, A. (2012). Sound governance. Engaging citizens through collaborative organizations. Public Organization Review, 12(3), 223-241.

Fountain, J. (2001). Building the Virtual State. Washington DC: Brookings.

Feeney, M. K., \& Welch, E. W. (2014). Technology-Task Coupling Exploring Social Media Use and Managerial Perceptions of E-Government. The American Review of Public Administration. doi: $10.1177 / 0275074014547413$.

Fuchs, C. (2008). Internet and society: Social theory in the information age. New York: Routledge. Gray, R. (2002). The social accounting project and accounting organizations and society: Privileging engagement, imaginings, new accountings and pragmatism over critique?. Accounting Organizations and Society, 27(7), 687-708.

Greve, C. (2015), Ideas in Public Management Reform for the 2010s: Digitalization, Value Creation and Involvement. Public Organization Review, 15(1), 49-65.

Habermas, J. (1984). The theory of communicative action. 1: reason and the rationalization of society. Boston: Beacon Press. 
Habermas, J.: (1987). The theory of communicative action. 2: lifeworld and system: a critique of functional reason. Boston: Beacon Press.

Habermas, J. (1989). The structural transformation of the public sphere. Cambridge: Polity Press.

Haveri, A. (2006). Complexity in Local Government Change: Limits to Rational Reforming. Public Management Review, 8(10), 31-46.

Holzer, M., \& Manoharan, A. (2008). Opportunities for civic engagement. In K. Yang \& E.

Bergrud (Eds.), Civic engagement in a network society. Charlotte, NC: Information Age Publishing.

Hood, C. (1991). A Public Management for All Seasons? Public Administration, 69(1), 3-19.

Kaplan A. M. \& Haenlein M., (2012). Social media: back to the roots and back to the future. Journal of Systems and Information Technology. 14(2), 101-104

Kaplan, A. M., \& Haenlein, M. (2009). Consumers, companies, and virtual social worlds: A qualitative analysis of Second Life. Advances in Consumer Research, 36(1), 873—874.

Kaplan, A. M., \& Haenlein, M. (2010). Users of the world, unite! The challenges and opportunities of social media. Business Horizons, 53(1), 59-68.

Kent, M.L., Taylor, M. \& White, W. (2003). The relationship between Web site design and organizational responsiveness to stakeholders. Public Relations Review, 29(1), 66-77.

King, C., \& Stivers, C. (1998). Government Is Us: Public Administration in an Anti-government Era. Thousand Oaks, CA: Sage Publication

Kramer, K. \& King, J. (1986). Computing and public organizations. Public Administration Review, 46, 488-496.

Landsbergen, D., \& Park, J. (2011). Managing Network Communications Through Social Media. Paper presented to the Public Management Research Conference in Syracuse, New York 2-4 June 2011. Paper available at http://www.maxwell.syr.edu/deans.aspx?id=77309416873

Laughlin, R. (2007). Critical reflections on research approaches accounting regulation and the regulation of accounting. British Accounting Review, 39(4), 271-289.

Laughlin, R.C. (1987). Accounting systems in organizational contexts: A case for critical theory. Accounting Organizations and Society, 12(5), 479-502.

Li, M. H., \& Feeney, M. K. (2014). Adoption of Electronic Technologies in Local US Governments Distinguishing Between E-Services and Communication Technologies. The American Review of Public Administration, 44(1), 75-91. 
Lovejoy, K., Waters, R.D. \& Saxton, G.D. (2012). Engaging stakeholders through Twitter: How non-profit organizations are getting more out of 140 characters or less. Public Relations Review 38(2), 313-318.

Ma, Liang (2014). Diffusion and assimilation of government microblogging: Evidence from Chinese cities. Public Management Review, 16(2), 274-295.

Manetti, G. (2011). The Quality of Stakeholder Engagement in Sustainability Reporting: Empirical Evidence and Critical Points. Corporate Social Responsibility and Environmental Management, $18(2), 110-122$.

Mansbridge, J.J. (1994). Public spirit in political systems. In H.J.Aron, T.E Mann \& T.Taylor (Eds.),Values And public policy, 146-172.Washington DC: Brookings Institution.

Meijer, A. and Thaens, M. (2010). Alignment 2.0: strategic use of new internet technologies in government. Government Information Quarterly, 27(2), 113-121.

Meijer, A. J., \& Torenvlied, R. (2014). Social Media and the New Organization of Government Communications An Empirical Analysis of Twitter Usage by the Dutch Police. The American Review of Public Administration, Published online before print September 28, 2014, doi: $10.1177 / 0275074014551381$.

Mergel, I. (2012). Social Media in the Public Sector. San Francisco: Jossey Bass.

Mergel, I. (2013). A Framework for Interpreting Social Media Interactions in the Public Sector, in: Government Information Quarterly, 30(4), 327-334.

Mitchell, R. K., Agle, B. R. \& Wood, D. J. (1997). Toward a Theory of Stakeholder Identification and Salience: Defining the Principle of Who and What Really Counts. Academy of Management Review, 22(4), 853-886.

Newman, J., \& Clarke, J. (2009). Publics, Politics and Power. London: Sage.

O'Dwyer, B. (2005). The construction of a social account: a case study in an overseas aid agency. Accounting, Organizations and Society, 30(3), 279-296.

OECD. (2010). Value for Money: Public Administration after “New Public Management”. Paris: OECD.

Osborne, S. (Ed.) (2010). The New Public Governance?. London: Routledge.

Ostrom, V. \& Ostrom, E. (1971). Public Choice: A Different Approach to the Study of Public Administration. Public Administration Review, 31: 203-16. 
Park, H. \& Reber, B.M. (2008). Relationship building and the use of Web sites: How Fortune 500 corporations use their Web sites to build relationships. Public Relations Review, 34, 409-411.

Patten, D. \& Guidry, R. (2010). Market reactions to the first-time issuance of corporate sustainability reports: Evidence that quality matters. Sustainability Accounting, Management and Policy Journal, 1(1): 33-50.

Pfeffer, J. \& Salancik, G. (1978). The External Control of Organizations: A Resource Dependence Perspective. New Yokr: Harper \& Row.

Porter, M. E. (2001). Strategy and the Internet. Harvard business review, 79(3), 62-79.

Power, M. \& Laughlin, R.C. (1996). Habermas law and accounting. Accounting Organizations and Society, 21(5), 441-465.

Rybako, S., \& Seltzer, T. (2010). Dialogic communication in 140 characters or less: How Fortune 500 companies engage stakeholders using Twitter. Public Relations Review, 36(4), 336-341.

Sandel, M. (1996). Democracy = Discontent. Cambridge, MA: Belknap Press of Harvard University Press.

Simon, H.A. (1957) Models of Man. New York: Wiley \& Sons

Suchman, M. (1995). Managing legitimacy: Strategic and institutional approaches. Academy of Management Review, 20(3), 517-610.

Surowiecki, J. (2004). The Wisdom of Crowds, New York: Little, Brown.

Svendsen, A. (1998). The Stakeholder Strategy: Profiting from Collaborative Business Relationships. San Francisco CA: Berett-Koehler.

Swift, T., Owen, D.L. \& Humphrey, C. (2001). The management information systems dimensions of social and environmental accounting and accountability. London: CIMA Research.

Tate, W.L., Ellran, L.S. \& Kirchoff, J.F. (2010). Responsibility reports: A thematic analysis related to supply chain management. Journal of Supply Chain Management, 46(1), 19-44.

Teicher, J., Alam, Q. \& Van Gramberg, B. (2006). Managing Trust and Relationships in PPPs: Some Australian Experiences. International Review of Administrative Sciences. 72(1), 85-100.

Transit Cooperative Research Program (2012). Uses of social media in public transportation. A Synthesis of Transit Practice. Washington DC, National Academy Of Sciences.

Unerman, J. \& Bennett, M. (2004). Increased stakeholder dialogue and the internet: towards greater corporate accountability or reinforcing capitalist hegemony? Accounting, Organizations and 
Society, 29(7), 685-707.

Villa, D.R. (1992). Postmodernism and the Public Sphere. American Political Science Review, 86(3), 712-721.

Voss, Z. G., Voss, G. B. \& Moorman, C. (2005). An empirical examination of the complex relationships between entrepreneurial orientation and stakeholder support. European Journal of Marketing, 39(9/10), 1132-1150.

Waddock, S. A. (2002). Leading Corporate Citizens: Vision, Values, Value Added. Boston: Mc Graw-Hill.

Waters, R.D. \& Jamal, J.Y. (2011). Tweet, tweet, tweet: A content analysis of non-profit organizations Twitter updates. Public Relations Review, 37(3), 321-324.

Windsor, D. (2002). Stakeholder Responsibilities: Lessons for Managers. In J. Andriof, S. Waddock, B. Husted \& S. Rahman (ed.), Unfonding Stakeholder Thinking: Theory, Responsibility and Engagement (pp. 137-154). Sheffield: Greenleag Publishing.

Xifra, J., \& Grau, F. (2010). Nanoblogging PR: The discourse on public relations in Twitter. Public Relations Review, 36(2), 171-174. 
Table 1 - List of public transportation agencies and descriptive statistics

\begin{tabular}{|c|c|c|c|c|c|c|c|c|c|}
\hline \multirow[b]{2}{*}{ Agency name } & \multirow[b]{2}{*}{ State } & \multicolumn{4}{|c|}{ Facebook } & \multicolumn{4}{|c|}{ Twitter } \\
\hline & & Posts & $\begin{array}{c}\text { Average \# } \\
\text { Likes }\end{array}$ & $\begin{array}{c}\text { Average } \\
\text { \# Sharing }\end{array}$ & $\begin{array}{l}\text { Average \# } \\
\text { Comments }\end{array}$ & Tweets & $\begin{array}{l}\text { Average \# } \\
\text { Favourites }\end{array}$ & $\begin{array}{c}\text { Average \# } \\
\text { Retweet }\end{array}$ & $\begin{array}{c}\text { Average \# } \\
\text { Replies }\end{array}$ \\
\hline Bay Area Rapid Transit & Oakland CA & 21 & 25.19 & 4.10 & 6.38 & 100 & 10.23 & 11.14 & 1.67 \\
\hline Capital Area Transportation Authority & Lansing MI & 58 & 2.81 & 0.62 & 0.24 & 48 & 0.56 & 1.13 & 0.08 \\
\hline CDTA & Albany NY & 20 & 4.95 & 0.20 & 0.70 & 100 & 0.35 & 0.46 & 0.00 \\
\hline Centre Area Transportation Authority & State College PA & 32 & 7.09 & 0.56 & 1.41 & 33 & 0.76 & 0.76 & 0.36 \\
\hline Chapel Hill Transit & Chapel Hill NC & 10 & 1.20 & 0.00 & 0.10 & 10 & 0.90 & 2.60 & 0.20 \\
\hline Community Transit & Everett WA & 20 & 36.55 & 3.70 & 5.75 & 100 & 0.76 & 0.36 & 0.04 \\
\hline Dallas Area Rapid Transit & Dallas TX & 17 & 17.71 & 3.53 & 6.82 & 29 & 1.72 & 4.14 & 0.48 \\
\hline Des Moines Area Regional Transit Authority & Des Moines IA & 57 & 2.09 & 0.70 & 0.19 & 71 & 0.61 & 0.66 & 0.14 \\
\hline Edmonton Transit & Edmonton AB & 46 & 55.43 & 15.59 & 11.11 & 100 & 0.15 & 0.26 & 0.00 \\
\hline Greater Cleveland RTA & Cleveland $\mathrm{OH}$ & 24 & 5.79 & 0.46 & 2.75 & 100 & 0.37 & 0.60 & 0.05 \\
\hline Hillsborough Area Regional Transit & Tampa FL & 47 & 14.98 & 2.55 & 2.70 & 100 & 0.66 & 0.70 & 0.08 \\
\hline Johnson County Transit & Olathe KS & 12 & 1.50 & 0.00 & 0.75 & 50 & 0.40 & 0.38 & 0.22 \\
\hline King Country Metro Transit & Seattle WA & 21 & 17.71 & 5.14 & 1.81 & 100 & 0.97 & 1.68 & 0.28 \\
\hline Kitsap Transit & Bremerton WA & 28 & 2.71 & 1.04 & 0.36 & na & na & na & na \\
\hline LANTA & Allentown PA & 19 & 10.84 & 1.53 & 1.63 & 46 & 0.33 & 0.28 & 0.09 \\
\hline $\begin{array}{l}\text { Los Angeles County Metropolitan } \\
\text { Transportation Authority }\end{array}$ & Los Angeles CA & 100 & 91.63 & 10.54 & 4.17 & 100 & 2.62 & 2.97 & 0.32 \\
\hline Manchester Transit Authority & Manchester NH & 11 & 4.64 & 2.18 & 0.45 & 7 & 0.14 & 0.29 & 0.00 \\
\hline Metrolink & Los Angeles CA & 100 & 112.50 & 5.40 & 5.52 & 100 & 0.72 & 0.45 & 0.08 \\
\hline Metropolitan Atlanta Rapid Transit Authority & Atlanta GA & 19 & 9.84 & 1.47 & 1.68 & 100 & 0.14 & 0.28 & 0.02 \\
\hline Mountain Line Transit Authority & New York NY & 5 & 1.20 & 0.00 & 0.20 & 73 & 0.22 & 0.11 & 0.11 \\
\hline MTA & Morgantown WV & 15 & 247.60 & 62.60 & 32.47 & 88 & 7.16 & 7.55 & 1.45 \\
\hline NJ TRANSIT & Newark NJ & 30 & 41.43 & 2.17 & 10.27 & 99 & 1.37 & 3.77 & 1.68 \\
\hline
\end{tabular}




\begin{tabular}{|c|c|c|c|c|c|c|c|c|c|}
\hline Pinellas Suncoast Transit Authority & St. Petersburg FL & 100 & 3.38 & 0.15 & 0.15 & 100 & 0.86 & 0.37 & 0.04 \\
\hline Port Authority of Allegheny Country & Pittsburgh PA & na & na & na & na & 100 & 0.62 & 2.03 & 0.17 \\
\hline $\begin{array}{l}\text { Potomac and Rappahannock Transportation } \\
\text { Commission }\end{array}$ & Woodbridge VA & 19 & 2.42 & 0.05 & 0.26 & na & na & na & na \\
\hline Societe de Transport de Montreal & Montréal QC & 27 & 24.41 & 4.96 & 6.11 & 61 & 0.97 & 3.05 & 0.34 \\
\hline Sound Transit & Seattle WA & 28 & 47.36 & 8.82 & 7.46 & 100 & 3.72 & 3.62 & 1.26 \\
\hline St. Louis Metro Transit & St. Louis MO & 100 & 1.20 & 0.19 & 0.14 & 100 & 1.03 & 1.26 & 0.31 \\
\hline The Rapid & Grand Rapids MI & 80 & 14.49 & 1.91 & 2.88 & 100 & 0.77 & 0.45 & 0.02 \\
\hline Toronto Transit Commission & Toronto ON & 22 & 34.27 & 18.64 & 12.09 & 100 & 0.85 & 2.21 & 0.54 \\
\hline Translink & Vancouver BC & 83 & 24.47 & 6.04 & 9.46 & 100 & 0.57 & 0.45 & 0.08 \\
\hline Triangle Transit & Durham NC & 4 & 4.50 & 0.25 & 1.00 & na & na & na & na \\
\hline TRIMET & Portland OR & 18 & 213.17 & 98.06 & 21.56 & 100 & 1.36 & 5.15 & 1.37 \\
\hline $\begin{array}{l}\text { Washington Metropolitan Area Transit } \\
\text { Authority }\end{array}$ & Washington DC & 29 & 61.52 & 111.10 & 7.24 & 100 & 0.35 & 3.98 & 0.78 \\
\hline Winnipeg Transit System & Winnipeg MB & na & na & na & na & 100 & 0.17 & 0.24 & 0.43 \\
\hline AGGREGATE & & 1222 & 35.95 & 8.55 & 4.37 & 2615 & 1.44 & 2.07 & 0.43 \\
\hline STANDARD DEVIATION & & 30.16 & 57.17 & 26.57 & 6.85 & 29.48 & 2.10 & 2.45 & 0.51 \\
\hline
\end{tabular}


Table 2 - Number of posts and tweets categorised by content for each agency

\begin{tabular}{|c|c|c|c|c|c|c|c|c|c|c|c|c|c|c|c|c|c|c|}
\hline \multirow[b]{3}{*}{ Agency name } & \multicolumn{7}{|c|}{ Type of posts } & \multirow[b]{3}{*}{$\begin{array}{l}\text { Total } \\
\text { posts }\end{array}$} & \multicolumn{9}{|c|}{ Type of tweets } & \multirow[b]{3}{*}{$\begin{array}{l}\text { Total } \\
\text { tweets }\end{array}$} \\
\hline & & If SE, & which s & akeho & der: & & & & \multirow[b]{2}{*}{ SE } & \multicolumn{6}{|c|}{ If SE, which stakeholder: } & \multirow[b]{2}{*}{ PI } & \multirow[b]{2}{*}{$\mathbf{O}$} & \\
\hline & SE & نَّ & 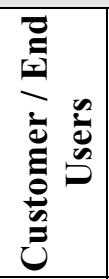 & 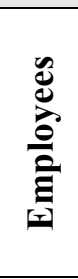 & 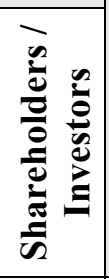 & PI & $\mathbf{O}$ & & & 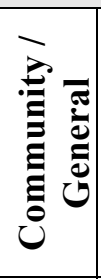 & 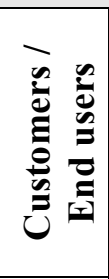 & $\frac{\stackrel{n}{0}}{\stackrel{0}{0}}$ & 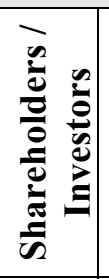 & 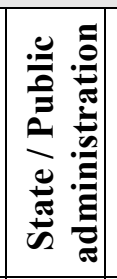 & 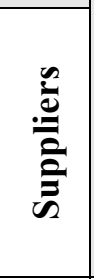 & & & \\
\hline Bay Area Rapid Transit & 4 & & & & 4 & 5 & 12 & 21 & 6 & & 4 & & 2 & & & 66 & 28 & 100 \\
\hline Capital Area Transportation Authority & 10 & 8 & 2 & & & 24 & 24 & 58 & 4 & 4 & 0 & & & & & 28 & 16 & 48 \\
\hline CDTA & 3 & 1 & 2 & & & 8 & 9 & 20 & 15 & 9 & 5 & 1 & & & & 46 & 39 & 100 \\
\hline Centre Area Transportation Authority & 11 & 5 & 4 & 2 & & 9 & 12 & 32 & 15 & 6 & 4 & 5 & & & & 7 & 11 & 33 \\
\hline Chapel Hill Transit & 2 & & 1 & 1 & & 6 & 2 & 10 & 2 & & 1 & 1 & & & & 6 & 2 & 10 \\
\hline Community Transit & 3 & & 2 & 1 & & 8 & 9 & 20 & 65 & 10 & 49 & 5 & 1 & & & 15 & 20 & 100 \\
\hline Dallas Area Rapid Transit & 3 & 3 & 0 & & & 5 & 9 & 17 & 8 & 2 & 6 & & & & & 8 & 13 & 29 \\
\hline $\begin{array}{l}\text { Des Moines Area Regional Transit } \\
\text { Authority }\end{array}$ & 18 & 9 & 6 & 1 & 2 & 18 & 21 & 57 & 12 & 1 & 9 & & 2 & & & 23 & 36 & 71 \\
\hline Edmonton Transit & 8 & 2 & 5 & & 1 & 18 & 20 & 46 & & & 0 & & & & & 92 & 8 & 100 \\
\hline Greater Cleveland RTA & 7 & 2 & 5 & & & 7 & 10 & 24 & 9 & 2 & 7 & & & & & 82 & 9 & 100 \\
\hline Hillsborough Area Regional Transit & 13 & 4 & 1 & 2 & 6 & 20 & 14 & 47 & 11 & 5 & 3 & 1 & 2 & & & 54 & 35 & 100 \\
\hline Johnson County Transit & 2 & & 1 & & 1 & 6 & 4 & 12 & 2 & & 0 & 1 & 1 & & & 27 & 21 & 50 \\
\hline King Country Metro Transit & 10 & 4 & 2 & 4 & & 7 & 4 & 21 & 14 & 7 & 5 & 2 & & & & 71 & 15 & 100 \\
\hline Kitsap Transit & 11 & 7 & 3 & 1 & & 14 & 3 & 28 & & & & & & & & & & \\
\hline LANTA & 1 & & 1 & & & 7 & 11 & 19 & 6 & 1 & 3 & 2 & & & & 16 & 24 & 46 \\
\hline $\begin{array}{l}\text { Los Angeles County Metropolitan } \\
\text { Transportation Authority }\end{array}$ & 13 & 10 & 3 & & & 32 & 55 & 100 & 6 & & 5 & & 1 & & & 79 & 15 & 100 \\
\hline Manchester Transit Authority & 1 & & 0 & 1 & & 10 & & 11 & & & 0 & & & & & 7 & & 7 \\
\hline Metrolink & & & 0 & & & 57 & 43 & 100 & 1 & & 0 & & 1 & & & 97 & 2 & 100 \\
\hline Metropolitan Atlanta Rapid Transit & 1 & 1 & 0 & & & 12 & 6 & 19 & 6 & & 6 & & & & & 94 & & 100 \\
\hline
\end{tabular}




\begin{tabular}{|c|c|c|c|c|c|c|c|c|c|c|c|c|c|c|c|c|c|c|}
\hline Authority & & & & & & & & & & & & & & & & & & \\
\hline Mountain Line Transit Authority & 3 & 1 & 1 & 1 & & 1 & 1 & 5 & 19 & 5 & 11 & 2 & 1 & & & 37 & 17 & 73 \\
\hline MTA & 4 & & 4 & & & 3 & 8 & 15 & 24 & 16 & 6 & & 1 & & 1 & 20 & 44 & 88 \\
\hline NJ TRANSIT & 17 & 5 & 12 & & & 5 & 8 & 30 & 19 & 1 & 17 & 1 & & & & 77 & 3 & 99 \\
\hline Pinellas Suncoast Transit Authority & 51 & 36 & 8 & 6 & 1 & 4 & 45 & 100 & 30 & 14 & 3 & 13 & & & & 16 & 54 & 100 \\
\hline Port Authority of Allegheny Country & & & & & & & & & 13 & & 11 & & 2 & & & 84 & 3 & 100 \\
\hline $\begin{array}{l}\text { Potomac and Rappahannock } \\
\text { Transportation Commission }\end{array}$ & 11 & 2 & 9 & & & 5 & 3 & 19 & & & & & & & & & & \\
\hline Societe de Transport de Montreal & 12 & 7 & 5 & & & 2 & 13 & 27 & 10 & 4 & 6 & & & & & 49 & 2 & 61 \\
\hline Sound Transit & 11 & 4 & 7 & & & 3 & 14 & 28 & 24 & 13 & 11 & & & & & 34 & 42 & 100 \\
\hline St. Louis Metro Transit & 19 & 17 & 2 & & & 53 & 28 & 100 & 9 & 5 & 3 & & & 1 & & 67 & 24 & 100 \\
\hline The Rapid & 24 & 8 & 8 & 7 & 1 & 20 & 36 & 80 & 33 & 15 & 10 & 8 & & & & 14 & 53 & 100 \\
\hline Toronto Transit Commission & 6 & & 6 & & & 12 & 4 & 22 & & & 0 & & & & & 100 & & 100 \\
\hline Translink & 15 & 4 & 5 & & 6 & 27 & 41 & 83 & 6 & & 6 & & & & & 92 & 2 & 100 \\
\hline Triangle Transit & 1 & & 0 & & 1 & 1 & 2 & 4 & & & & & & & & & & \\
\hline TRIMET & 5 & 1 & 2 & 2 & & 3 & 10 & 18 & & & 0 & & & & & 99 & 1 & 100 \\
\hline $\begin{array}{l}\text { Washington Metropolitan Area Transit } \\
\text { Authority }\end{array}$ & 4 & & 3 & 1 & & 15 & 10 & 29 & & & 0 & & & & & 100 & & 100 \\
\hline Winnipeg Transit System & & & & & & & & & 83 & & 83 & & & & & 14 & 3 & 100 \\
\hline TOTAL & 304 & 141 & 110 & 30 & 23 & 427 & 491 & 1222 & 452 & 120 & 274 & 42 & 14 & 1 & 1 & 1621 & 542 & 2615 \\
\hline PERCENTAGE & 24.8 & 11.54 & 9.00 & 2.45 & 1.88 & 34.94 & 40.18 & 100 & 17.28 & 4.59 & 10.48 & 1.61 & 0.54 & 0.04 & 0.04 & 61.99 & 20.73 & 100 \\
\hline
\end{tabular}




\section{Table 3 - Transcript of a sample Facebook post for stakeholder engagement}

\section{Post published by the agency}

\section{Metro Forward}

June 12, 2014 [Post's privacy set to "Public"]

[Photo of a smiling driver]

Metro is looking to hire over 200 Bus Operators this summer! Looking for a career with growth opportunities? This is the position for you.

Minimum qualifications: high school diploma or GED; valid driver's license; 3 years of post-HS employment or 3 years of full/part-time student status \& employment history. Visit [URL] and search for job code 150268. \#wmatajobs \#wmatacareers

[469 likes] [128 comments] [3,004 shares]

\begin{tabular}{|l|c|c|}
\hline Examples of comment & $\begin{array}{c}\text { Examples of replies by the } \\
\text { agency }\end{array}$ & $\begin{array}{c}\text { Examples of replies by other } \\
\text { Facebook users }\end{array}$ \\
\hline $\begin{array}{l}\text { I got my CDL permit but not the } \\
\text { license. Does Metro provide } \\
\text { training to obtain my license? [4 } \\
\text { likes, 11 replies] }\end{array}$ & $\begin{array}{c}\text { [Metro Forward] Yes, we do } \\
\text { assist CDL permit holders with } \\
\text { obtaining their licenses. [7 likes] }\end{array}$ & $\begin{array}{c}\text { Last I heard a couple of months } \\
\text { ago they couldn't.... Lost the } \\
\text { license to train. My barber work } \\
\text { for metro [2 likes] }\end{array}$ \\
\cline { 2 - 3 } $\begin{array}{l}\text { Someone told me metro don't } \\
\text { hire felons is this true???? [3 }\end{array}$ & $\begin{array}{c}\text { I applied a few months ago and } \\
\text { received a email stating what } \\
\text { [ikes, 0 replies] }\end{array}$ & $\begin{array}{c}\text { [another user] said... [0 likes] } \\
\text { It depends on your charge, some } \\
\text { felonies are except if they are } \\
\text { over 10 years and some are } \\
\text { indefinite. They will tell you } \\
\text { what charges will disqualify you } \\
\text { before you take the test. [0 likes] }\end{array}$ \\
\hline
\end{tabular}




\section{Table 4 - Transcript of a sample Tweet containing public information}

\begin{tabular}{|c|c|c|}
\hline \multicolumn{3}{|l|}{ Post } \\
\hline \multicolumn{3}{|c|}{$\begin{array}{l}@ \text { SFBART [Bay Area Rapid Transport] } \\
\text { June } 24,2015\end{array}$} \\
\hline \multicolumn{3}{|c|}{$\begin{array}{l}\text { [Map of the disrupted lines] } \\
\text { No train service between } S F \text { \& East Bay during } 2 \text { upcoming weekends. [link to a page with more details] }\end{array}$} \\
\hline \multicolumn{3}{|c|}{ [37 favourites] [22 replies] [120 retweet] } \\
\hline Examples of replies & $\begin{array}{l}\text { Examples of replies by the } \\
\text { agency }\end{array}$ & $\begin{array}{l}\text { Examples of replies by other } \\
\text { Twitter users }\end{array}$ \\
\hline $\begin{array}{l}@ \text { SFBART Please be more } \\
\text { specific about the affected } \\
\text { weekends. [1 reply] }\end{array}$ & $\begin{array}{c}\text { @ [username] Thanks for asking. } \\
\text { Attached is weekend service } \\
\text { details for Aug 1-2, Sep 5-7 at } \\
\text { http://ow.ly/d/3rpm or } \\
\text { http://ow.ly/OKOL4 }\end{array}$ & - \\
\hline $\begin{array}{l}\text { @ SFBART @ [other username] } \\
\text { So presumably, people headed to } \\
\text { WO would have to make their } \\
\text { own way from } 19 \text { th st? No bus } \\
\text { bridge there? [ } 1 \text { reply] }\end{array}$ & $\begin{array}{l}\text { @ [username] Yes, \#SFBART } \\
\text { bus bridge is } 19 \text { th St station to } \\
\text { temporary Transbay Terminal. } \\
\text { Riders can call 510-465-BART } \\
\text { for @ rideact options }\end{array}$ & - \\
\hline $\begin{array}{l}\text { @ SFBART Thanks for \#tweeting } \\
\text { this alert \#sfbart! \#sanfrancisco } \\
\text { \#sfbayarea \#publictransit } \\
\text { \#oakland \#eastbay \#trains } \\
\text { \#infrastructure \#repairs [0 } \\
\text { replies] }\end{array}$ & - & - \\
\hline
\end{tabular}


Table 5 - Social media data on interaction by type of Facebook post and tweet

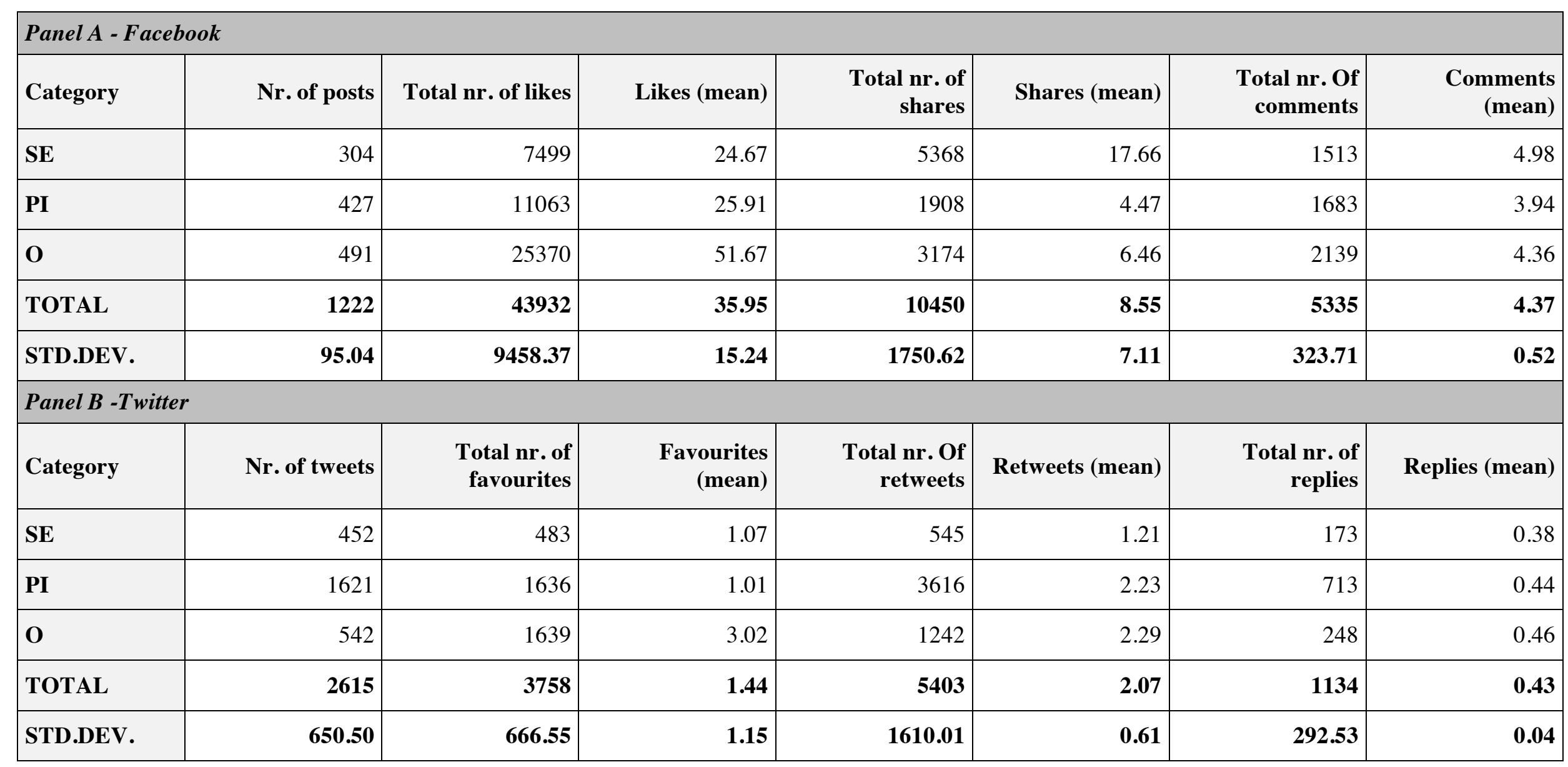


Table 6 - Level of interaction and tenor of comments/replies for Facebook and Twitter

\begin{tabular}{|c|c|c|c|c|c|c|c|}
\hline \multicolumn{8}{|c|}{ Panel A - Facebook } \\
\hline Category & Nr. of posts & $\begin{array}{r}\text { Nr. of posts with } \\
\text { comments }\end{array}$ & $\begin{array}{r}\text { Nr. of posts with } \\
\text { replies from } \\
\text { other users }\end{array}$ & $\begin{array}{r}\text { Nr. of posts with } \\
\text { replies from the } \\
\text { agency }\end{array}$ & $\begin{array}{r}\text { Interaction index } \\
\text { (users) }\end{array}$ & $\begin{array}{r}\text { Interaction index } \\
\text { (agency) }\end{array}$ & $\begin{array}{r}\text { Tenor of } \\
\text { comments (index) }\end{array}$ \\
\hline SE & 304 & 140 & 65 & 60 & 0.464 & 0.429 & 2.829 \\
\hline PI & 427 & 203 & 90 & 86 & 0.443 & 0.424 & 2.724 \\
\hline $\mathbf{O}$ & 491 & 274 & 113 & 85 & 0.412 & 0.310 & 3.172 \\
\hline TOTAL & 1222 & 617 & 268 & 231 & 0.434 & 0.374 & 2.947 \\
\hline STD.DEV. & 95.04 & 67.04 & 24.01 & 14.73 & 0.03 & 0.07 & 0.23 \\
\hline \multicolumn{8}{|c|}{ Panel B - Twitter } \\
\hline Category & Nr. of tweets & $\begin{array}{r}\text { Nt. of tweets with } \\
\text { replies }\end{array}$ & $\begin{array}{r}\text { Nr.of tweets with } \\
\text { replies from } \\
\text { other users }\end{array}$ & $\begin{array}{r}\text { Nr. of tweets with } \\
\text { replies from the } \\
\text { agency }\end{array}$ & $\begin{array}{r}\text { Interaction index } \\
\text { (users) }\end{array}$ & $\begin{array}{r}\text { Interaction index } \\
\text { (agency) }\end{array}$ & $\begin{array}{r}\text { Tenor of replies } \\
\text { (index) }\end{array}$ \\
\hline SE & 452 & 78 & 6 & 24 & 0.077 & 0.308 & 2.897 \\
\hline PI & 1621 & 268 & 18 & 62 & 0.067 & 0.231 & 2.306 \\
\hline $\mathbf{O}$ & 542 & 104 & 9 & 18 & 0.087 & 0.173 & 2.808 \\
\hline TOTAL & 2615 & 450 & 33 & 104 & 0.073 & 0.231 & 2.524 \\
\hline STD.DEV. & 650.50 & 103.01 & 6.24 & 23.86 & 0.01 & 0.07 & 0.32 \\
\hline
\end{tabular}

